ORIGINAL ARTICLE

\title{
PERILAKU MAHASISWA TERKAIT CARA MENGATASI JERAWAT
}

\author{
Retno Try Lestari, Lailatul Zakiyah Gifanda, Erika Lailia Kurniasari, Ragilia Puspita Harwiningrum, \\ Ardiansyah Putranda Ilham Kelana, Kholidatul Fauziyah, Setia Laili Widyasari, Tiffany, Dewi Islamiah \\ Krisimonika, Daniel Dwi Christiananta Salean, Yuni Priyandani* \\ Fakultas Farmasi, Universitas Airlangga \\ Gedung Nanizar Zaman Joenoes Kampus C, J1. Ir. Soekarno, Surabaya 60115, Indonesia \\ E-mail: yuni-p@ff.unair.ac.id
}

\begin{abstract}
ABSTRAK
Acne vulgaris (jerawat) adalah penyakit kulit akibat peradangan kronis dengan patogenesis kompleks yang melibatkan beberapa komponen. Jerawat menyerang $85 \%$ populasi dunia yang berusia 11-30 tahun. Salah satu cara mengatasi jerawat adalah dengan menggunakan produk antiacne. Namun, kekeliruan pemilihan produk antiacne dapat menimbulkan efek yang tidak diinginkan. Tujuan dari penelitian ini adalah untuk mengetahui pengetahuan, sikap, dan tindakan mahasiswa mengenai jerawat dan cara mengatasinya. Penelitian ini merupakan penelitian cross sectional dengan instrumen berupa kuesioner yang dilakukan secara interview administered questionnaire. Teknik pengambilan sampel dilakukan secara accidental sampling. Survei ini diikuti oleh 120 mahasiswa dengan rentang usia 17-23 tahun. Hasil penelitian menunjukkan bahwa dari 120 responden, sebesar 98,3\% responden pernah berjerawat, 60,8\% responden beranggapan bahwa salep antiacne yang sudah digunakan dan masih tersisa dapat digunakan lagi hingga tanggal kedaluwarsa, 75,0\% responden merasa tidak perlu berkonsultasi dengan dokter umum/spesialis/klinik kecantikan ketika timbul jerawat, dan 97,0\% responden tidak ingin pergi ke klinik kecantikan ketika berjerawat.
\end{abstract}

Kata kunci: jerawat, antiacne, mahasiswa

\begin{abstract}
Acne vulgaris (acne) is a skin disease due to chronic inflammation with complex pathogenesis involving few components. Acne attacks $85 \%$ of the world's population aged 11-30 years. One of the ways to get over the acne is by using antiacne products. But inappropriate of antiacne products selection can cause some damages. The purpose of this study was to determine the frequency distribution between student's knowledge, attitudes, and actions regarding acne and how to overcome them. This research was a cross sectional study with questionnaire as media which was done by interview administered questionnaire. The sampling technique is done by accidental sampling. The survey was attended by 120 students aged 17-23 years. The results showed that $98.3 \%$ of respondents ever had acne, $60.8 \%$ of respondents thought that antiacne ointments that had been used and were still remaining could be used again until the expired date, $75.0 \%$ of respondents felt there was no need to consult a general practitioner/specialist/beauty clinic when acne arose, and $97.0 \%$ did not want to go to a beauty clinic when having acne.
\end{abstract}

Keywords: acne, antiacne, students 


\section{PENDAHULUAN}

Acne vulgaris (jerawat) adalah penyakit kulit akibat peradangan kronis dengan patogenesis kompleks, melibatkan kelenjar sebasea, hiperkeratinisasi folikular, kolonisasi bakteri berlebihan, reaksi imun tubuh, dan peradangan (Madelina dan Sulistyaningsih, 2018). Keberadaan bakteri Propiomibacterium acnes pada kulit dan terjadinya penyumbatan folikel sampai batas tertentu merupakan keadaan normal bagi semua orang. Perkembangan lesi secara klinis ditentukan oleh tingkat respons imun (hipersensitivitas) yang dipengaruhi secara genetik (Quairoli and Foster, 2009). Pemicu timbulnya jerawat antara lain genetik, aktivitas hormonal pada siklus menstruasi, stres, aktivitas kelenjar sebasea yang hiperaktif, kebersihan, makanan, dan penggunaan kosmetik. Jerawat disebabkan oleh penyumbatan pori kulit sehingga sekresi minyak menjadi terhambat kemudian membesar dan mengering menjadi jerawat (Muliyawan dan Suriana, 2013).

Peningkatan hormon estrogen dan progesteron pada remaja perempuan, dan hormon testosteron pada remaja laki-laki menyebabkan bertambahnya produksi kelenjar minyak dan keringat. Rambut dan muka menjadi berminyak sehingga minyak berlebih dapat menimbulkan jerawat pada wajah (Kemenkes RI, 2012).

Jerawat adalah penyakit kulit umum yang menyerang $85 \%$ populasi dunia yang berusia $11-30$ tahun (Okoro et al. 2016). Prevalensi penderita jerawat di Indonesia berkisar $80-85 \%$ pada remaja dengan puncak insiden usia 15-18 tahun, $12 \%$ pada wanita usia > 25 tahun dan 3\% pada usia 35-44 tahun (Resti dan Hendra, 2015).

Komplikasi atau dampak dari jerawat antara lain akne komedonal, akne papulo-pustuler, akne konglobata dan akne berat lainnya (Murtiastutik, 2009). Penderita jerawat memiliki kadar androgen serum dan kadar sebum lebih tinggi dibandingkan dengan orang normal meskipun kadar androgen serum penderita jerawat masih dalam batas normal (Movita, 2013).

Pencegahan jerawat dapat dilakukan dengan menjaga kebersihan kulit wajah. Kebersihan kulit wajah dimulai dengan mencuci muka dua kali sehari dengan sabun cuci muka atau cleanser. Selain itu, pencegahan jerawat dapat dilakukan dengan perawatan fisik seperti membersihkan komedo dengan menggunakan scrub atau porepack. Di sisi lain, jerawat akan bertambah parah apabila terlalu sering membersihkan wajah dengan sabun atau cleanser karena memicu kulit kering atau dehidrasi. Dehidrasi kulit dapat mengganggu lapisan kulit (stratum korneum) dalam proses deskuamasi alami (proses pelepasan lapisan sel kulit mati) sehingga risiko jerawat akan bertambah parah (Quairoli and Foster, 2009).

Pada dasarnya setiap individu memiliki kondisi kulit wajah yang berbeda-beda yang dipengaruhi oleh banyak faktor seperti gaya hidup dan hormon. Produk antiacne yang beredar sekarang ini memiliki kandungan dan tujuan yang bervariasi. Setiap pemilihan produk antiacne dapat disesuaikan dengan tipe wajah dan penyebab jerawat yang dimiliki. Secara umum, terdapat beberapa jenis kulit, yaitu kulit kering, kulit normal, kulit berminyak, dan kulit kombinasi. Pembagian ini didasarkan pada kandungan air dan minyak yang terdapat pada kulit. Kulit kering adalah kulit dengan kadar air kurang atau rendah. Kulit normal adalah kulit yang memiliki kadar air tinggi dan kadar minyak rendah sampai normal. Kulit berminyak yaitu kulit yang memiliki kandungan air dan minyak yang tinggi. Kulit campuran atau resisten dalam dunia kosmetika dikenal juga dengan istilah jenis kulit kombinasi, yaitu daerah bagian tengah atau dikenal juga dengan istilah zona $\mathrm{T}$ (dahi, hidung, dan dagu) terkadang berminyak atau normal, bagian kulit lain cenderung lebih normal bahkan kering (Muliyawan dan Suriana, 2013).

Kulit wajah cukup sensitif terhadap benda asing yang masuk dari luar tubuh termasuk produk antiacne. Kekeliruan dalam pemilihan produk antiacne dapat meningkatkan sensitivitas dan iritasi (Marliana dkk., 2018).

Perilaku merupakan keseluruhan pemahaman dan aktivitas seseorang yang merupakan hasil bersama antara faktor internal dan eksternal. Dalam perkembangannya, domain perilaku dikembangkan menjadi 3 tingkat ranah perilaku yakni pengetahuan (knowledge), sikap (attitude), dan tindakan atau praktik (practice) (Notoadmodjo, 2010).

Perubahan atau adopsi perilaku baru merupakan suatu proses yang kompleks dan memerlukan waktu yang relatif lama. Secara teori, perubahan perilaku seseorang menerima atau mengadopsi perilaku baru dalam kehidupannya melalui tiga tahap, yakni perubahan pengetahuan, perubahan sikap, dan perubahan tindakan (Notoadmodjo, 2012). Pada era saat ini, terdapat banyak pertimbangan dan solusi dalam memilih produk antiacne. Berdasarkan uraian diatas, maka penelitian ini bertujuan untuk mengetahui perilaku 
mahasiswa terkait masalah jerawat dan cara mengatasi jerawat.

\section{METODE PENELITIAN}

Penelitian ini merupakan penelitian cross sectional. Instrumen yang digunakan adalah interview administered questionnaire. Populasi sasaran penelitian ini ialah mahasiswa Institut Teknologi Sepuluh Nopember (ITS) dengan kriteria inklusi yaitu mahasiswa berusia 17-23 tahun dan bersedia mengisi form informed consent. Pengambilan sampel dilakukan secara accidental sampling. Variabel penelitian ini meliputi perlakuan terhadap jerawat (pencegahan jerawat dan perawatan jerawat), pemilihan produk antiacne (jenis produk dan informasi produk), dan penggunaan produk antiacne. Analisis data dilakukan secara deskriptif. Penentuan jumlah responden berdasarkan rumus perhitungan besar sampel, jika jumlah mahasiswa ITS 20.229 dengan $\mathrm{d}=0,1$ maka didapatkan jumlah sampel minimal 100 orang. Responden yang digunakan dalam penelitian ini sebanyak 120 orang sesuai kriteria inklusi.

\section{HASIL DAN PEMBAHASAN}

Berdasarkan hasil penelitian, seperti yang terlihat dalam Tabel 1, didapatkan data bahwa 118 responden $(98,3 \%)$ pernah berjerawat, 78 responden $(65,0 \%)$ mulai berjerawat pada usia $16-$ 20 tahun, 100 responden $(83,3 \%)$ mencuci muka sebelum tidur, 65 responden $(54,2 \%)$ menggunakan masker, 42 responden $(35,0 \%)$ mengatasi jerawat dengan memencet, 52 responden (43,3\%) menggunakan produk aloevera gel, dan 43 responden $(35,8 \%)$ menganggarkan <Rp50.000,00 untuk perawatan wajah. Beberapa responden telah melakukan tindakan yang tepat untuk mencegah dan mengatasi jerawat dengan penggunaan skincare dan tindakan pencegahan lainnya, namun beberapa responden melakukan tindakan yang tidak tepat seperti memencet jerawat $(35,0 \%)$ dan mengoleskan pasta gigi $(2,5 \%)$ sehingga perlu pemberian edukasi yang tepat.

Tabel 1. Deskriptif Karakteristik Responden

\begin{tabular}{ll}
\hline \multicolumn{1}{c}{ Profil } & Jumlah $(\%)$ \\
\hline Jenis Kelamin: & \\
Laki-laki & $51(42,5 \%)$ \\
Perempuan & $69(57,5 \%)$ \\
\hline Usia: & \\
$17-19$ tahun & $67(55,9 \%)$ \\
\hline
\end{tabular}

\begin{tabular}{|c|c|}
\hline 20-23 tahun & $53(44,1 \%)$ \\
\hline \multicolumn{2}{|l|}{ Pernah berjerawat: } \\
\hline $\mathrm{Ya}$ & $118(98,3 \%)$ \\
\hline Tidak & $2(1,7 \%)$ \\
\hline \multicolumn{2}{|l|}{ Usia Mulai Berjerawat: } \\
\hline $10-15$ tahun & $40(33,3 \%)$ \\
\hline 16-20 tahun & $78(65,0 \%)$ \\
\hline \multicolumn{2}{|l|}{ Tindakan Mencegah Jerawat: } \\
\hline Berkendara dengan masker & $35(29,2 \%)$ \\
\hline Cuci muka sebelum tidur & $100(83,3 \%)$ \\
\hline Tabir surya & $37(30,8 \%)$ \\
\hline Lainnya & $14(11,7 \%)$ \\
\hline \multicolumn{2}{|l|}{ Penggunaan skincare: } \\
\hline Ya & $91(75,8 \%)$ \\
\hline Tidak & $29(24,2 \%)$ \\
\hline \multicolumn{2}{|l|}{ Produk skincare yang digunakan: } \\
\hline Masker & $65(54,2 \%)$ \\
\hline Pelembab & $64(53,3 \%)$ \\
\hline Toner & $55(45,8 \%)$ \\
\hline Scrub & $48(40,0 \%)$ \\
\hline Serum & $23(19,2 \%)$ \\
\hline \multicolumn{2}{|l|}{ Tindakan Mengatasi Jerawat: } \\
\hline Membeli antiacne & $34(28,3 \%)$ \\
\hline Periksa ke dokter & $15(12,5 \%)$ \\
\hline Obat herbal & $19(15,8 \%)$ \\
\hline Mengikuti beauty influencer & $30(25,0 \%)$ \\
\hline Mengoleskan pasta gigi & $3(2,5 \%)$ \\
\hline Memencet jerawat & $42(35,0 \%)$ \\
\hline \multicolumn{2}{|l|}{ Produk Antiacne: } \\
\hline Sabun sulfur & $25(20,8 \%)$ \\
\hline Bedak Herocyn & $4(3,3 \%)$ \\
\hline Aloe vera gel & $52(43,3 \%)$ \\
\hline Verile gel & $8(6,7 \%)$ \\
\hline Acnol & $18(15,0 \%)$ \\
\hline \multicolumn{2}{|l|}{ Anggaran: } \\
\hline$<\operatorname{Rp} 50.000,-$ & $43(35,8 \%)$ \\
\hline Rp 50.000,--100.000,- & $28(23,3 \%)$ \\
\hline$>$ Rp 100.000,- & $30(25,0 \%)$ \\
\hline Lainnya & $16(13,3 \%)$ \\
\hline
\end{tabular}

Pengetahuan terhadap jerawat dan cara mengatasinya

Berdasarkan hasil penelitian pada 120 responden sebagaimana terlihat pada Tabel 2, sebanyak 73 responden $(60,8 \%)$ beranggapan bahwa salep antiacne yang sudah digunakan dan masih tersisa dapat digunakan lagi hingga tanggal kedaluwarsa. Padahal, terdapat Period After Opening (PAO) yaitu simbol yang menunjukkan lamanya masa pakai produk setelah kemasan dibuka. Simbol PAO berupa gambar kemasan yang terbuka disertai umur produk. Contohnya, jika tertulis $12 \mathrm{M}$, artinya masa berlaku produk setelah dibuka ialah 12 bulan. Hal ini patut untuk diperhatikan guna menjamin efektivitas produk. 
Tabel 2. Hasil Kuesioner Pengetahuan Mahasiswa

\begin{tabular}{|c|c|c|c|}
\hline \multirow[t]{2}{*}{ No } & \multirow[t]{2}{*}{ Pernyataan } & \multicolumn{2}{|c|}{$\begin{array}{l}\text { Pengetahuan Responden } \\
\text { Berdasarkan Kunci } \\
\text { Jawaban Kuesioner }\end{array}$} \\
\hline & & Sesuai & Tidak Sesuai \\
\hline \multicolumn{4}{|c|}{ Jerawat } \\
\hline 1. & $\begin{array}{l}\text { Jerawat adalah } \\
\text { peradangan kulit } \\
\text { akibat bakteri dan } \\
\text { kotoran }\end{array}$ & $\begin{array}{c}116 \\
(96,7 \%)\end{array}$ & $\begin{array}{c}4 \\
(3,3 \%)\end{array}$ \\
\hline 2. & $\begin{array}{l}\text { Terlalu sering } \\
\text { membersihkan wajah } \\
\text { dengan sabun cuci } \\
\text { muka, akan terhindar } \\
\text { dari timbulnya } \\
\text { jerawat }\end{array}$ & $\begin{array}{c}69 \\
(57,5 \%)\end{array}$ & $\begin{array}{c}51 \\
(42,5 \%)\end{array}$ \\
\hline 3. & $\begin{array}{l}\text { Jerawat dapat } \\
\text { bertambah parah jika } \\
\text { tidak diobati }\end{array}$ & $\begin{array}{c}73 \\
(60,8 \%)\end{array}$ & $\begin{array}{c}47 \\
(39,2 \%)\end{array}$ \\
\hline 4. & $\begin{array}{l}\text { Stres dapat } \\
\text { menyebabkan } \\
\text { timbulnya jerawat }\end{array}$ & $\begin{array}{c}114 \\
(95,0 \%)\end{array}$ & $\begin{array}{c}6 \\
(5,0 \%)\end{array}$ \\
\hline 5. & $\begin{array}{l}\text { Makanan berlemak } \\
\text { adalah salah satu } \\
\text { penyebab timbulnya } \\
\text { jerawat }\end{array}$ & $\begin{array}{c}110 \\
(91,7 \%)\end{array}$ & $\begin{array}{c}10 \\
(8,3 \%)\end{array}$ \\
\hline \multicolumn{4}{|c|}{ Produk antiacne } \\
\hline 6. & $\begin{array}{l}\text { Produk physical } \\
\text { treatment (scrub, } \\
\text { pore pack, dan } \\
\text { paper oil) dapat } \\
\text { mencegah timbulnya } \\
\text { jerawat }\end{array}$ & $\begin{array}{c}92 \\
(76,7 \%)\end{array}$ & $\begin{array}{c}28 \\
(23,3 \%)\end{array}$ \\
\hline 7. & $\begin{array}{l}\text { Salep antiacne yang } \\
\text { sudah digunakan dan } \\
\text { masih tersisa, dapat } \\
\text { digunakan lagi } \\
\text { sampai tanggal } \\
\text { kedaluwarsa }\end{array}$ & $\begin{array}{c}47 \\
(39,2 \%)\end{array}$ & $\begin{array}{c}73 \\
(60,8 \%)\end{array}$ \\
\hline 8. & $\begin{array}{l}\text { Pemilihan produk } \\
\text { antiacne harus } \\
\text { menyesuaikan tipe } \\
\text { kulit yang dimiliki }\end{array}$ & $\begin{array}{c}116 \\
(96,7 \%)\end{array}$ & $\begin{array}{c}4 \\
(3,3 \%)\end{array}$ \\
\hline 9. & $\begin{array}{l}\text { Asam salisilat adalah } \\
\text { salah satu komposisi } \\
\text { produk antiacne yang } \\
\text { memberikan khasiat }\end{array}$ & $\begin{array}{c}93 \\
(77,5 \%)\end{array}$ & $\begin{array}{c}27 \\
(22,5 \%)\end{array}$ \\
\hline 10. & $\begin{array}{l}\text { Semakin mahal } \\
\text { produk antiacne, } \\
\text { semakin terjamin } \\
\text { khasiat dan } \\
\text { kualitasnya }\end{array}$ & $\begin{array}{c}95 \\
(79,2 \%)\end{array}$ & $\begin{array}{c}25 \\
(20,8 \%)\end{array}$ \\
\hline
\end{tabular}

Sikap terhadap jerawat dan cara mengatasinya

Berdasarkan hasil penelitian pada 120 responden, pada Tabel 3 diketahui 90 responden $(75,0 \%)$ tidak merasa perlu berkonsultasi dengan dokter umum/spesialis/klinik kecantikan ketika timbul jerawat. Konsultasi dengan dokter bertujuan untuk mengidentifikasi tipe jerawat dan mendapatkan pengobatan yang tepat. Apabila pengatasan jerawat tidak tepat maka dapat memperparah kondisi jerawat tersebut. Oleh karena itu, penting untuk meningkatkan kesadaran dalam mengetahui jenis jerawat yang dialami terlebih dahulu yang kemudian diikuti dengan keputusan pemilihan produk antiacne yang tepat.

Tabel 3. Hasil Kuesioner Sikap Mahasiswa

\begin{tabular}{|c|c|c|c|}
\hline \multirow[t]{2}{*}{ No } & \multirow[t]{2}{*}{ Pernyataan } & \multicolumn{2}{|c|}{$\begin{array}{c}\text { Pengetahuan Responden } \\
\text { Berdasarkan Kunci } \\
\text { Jawaban Kuesioner }\end{array}$} \\
\hline & & Sesuai & Tidak Sesuai \\
\hline \multicolumn{4}{|c|}{ Jerawat } \\
\hline 1. & $\begin{array}{l}\text { Saya merasa tidak } \\
\text { terganggu dengan adanya } \\
\text { jerawat }\end{array}$ & $\begin{array}{c}80 \\
(66,7 \%)\end{array}$ & $\begin{array}{c}40 \\
(33,3 \%)\end{array}$ \\
\hline 2. & $\begin{array}{l}\text { Saya takut berjerawat jika } \\
\text { mencuci muka kurang dari } \\
\text { 2x sehari }\end{array}$ & $\begin{array}{c}49 \\
(40,8 \%)\end{array}$ & $\begin{array}{c}71 \\
(59,2 \%)\end{array}$ \\
\hline 3. & $\begin{array}{l}\text { Saya merasa perlu } \\
\text { berkonsultasi dengan } \\
\text { dokter umum / spesialis / } \\
\text { klinik kecantikan ketika } \\
\text { timbul jerawat }\end{array}$ & $\begin{array}{c}30 \\
(25,0 \%)\end{array}$ & $\begin{array}{c}90 \\
(75,0 \%)\end{array}$ \\
\hline 4. & $\begin{array}{l}\text { Saya takut berjerawat } \\
\text { ketika pola hidup saya } \\
\text { tidak teratur }\end{array}$ & $\begin{array}{c}76 \\
(63,3 \%)\end{array}$ & $\begin{array}{c}44 \\
(36,7 \%)\end{array}$ \\
\hline 5. & $\begin{array}{l}\text { Saya tidak khawatir timbul } \\
\text { jerawat meskipun banyak } \\
\text { memakan cokelat dan } \\
\text { junk food }\end{array}$ & $\begin{array}{c}59 \\
(49,2 \%)\end{array}$ & $\begin{array}{c}61 \\
(50,8 \%)\end{array}$ \\
\hline \multicolumn{4}{|c|}{ Produk antiacne } \\
\hline 6. & $\begin{array}{l}\text { Saya merasa perlu } \\
\text { membeli produk physical } \\
\text { treatments (scrub, pore } \\
\text { pack, dan paper oil) } \\
\text { untuk mencegah } \\
\text { berjerawat. }\end{array}$ & $\begin{array}{c}82 \\
(68,3 \%)\end{array}$ & $\begin{array}{c}38 \\
(31,7 \%)\end{array}$ \\
\hline 7. & $\begin{array}{l}\text { Saya merasa tidak perlu } \\
\text { membeli salep antiacne } \\
\text { ketika berjerawat }\end{array}$ & $\begin{array}{c}74 \\
(61,7 \%)\end{array}$ & $\begin{array}{c}46 \\
(38,3 \%)\end{array}$ \\
\hline 8. & $\begin{array}{l}\text { Saya peduli terhadap } \\
\text { pemilihan produk skincare } \\
\text { antiacne yang sesuai } \\
\text { dengan tipe kulit saya }\end{array}$ & $\begin{array}{c}93 \\
(77,5 \%)\end{array}$ & $\begin{array}{c}27 \\
(22,5 \%)\end{array}$ \\
\hline 9. & $\begin{array}{l}\text { Ketika membeli produk } \\
\text { antiacne, saya tidak peduli } \\
\text { dengan komposisi produk } \\
\text { yang tertulis pada kemasan }\end{array}$ & $\begin{array}{c}85 \\
(70,8 \%)\end{array}$ & $\begin{array}{c}35 \\
(29,2 \%)\end{array}$ \\
\hline 10. & $\begin{array}{l}\text { Saya selalu khawatir jika } \\
\text { membeli produk antiacne } \\
\text { yang murah karena } \\
\text { kualitasnya tidak terjamin. }\end{array}$ & $\begin{array}{c}45 \\
(37,5 \%)\end{array}$ & $\begin{array}{c}75 \\
(62,5 \%)\end{array}$ \\
\hline
\end{tabular}


Tindakan terhadap jerawat dan cara mengatasinya

Berdasarkan hasil penelitian pada 120 responden, pada Tabel 4 terlihat sebanyak 98 responden $(81,7 \%)$ tidak menghindari junk food atau cokelat dalam mencegah timbulnya jerawat.

Tabel 4. Hasil Kuesioner Tindakan Mahasiswa

\begin{tabular}{|c|c|c|c|}
\hline \multirow[t]{2}{*}{ No } & \multirow[t]{2}{*}{ Pernyataan } & \multicolumn{2}{|c|}{$\begin{array}{c}\text { Pengetahuan Responden } \\
\text { Berdasarkan Kunci } \\
\text { Jawaban Kuesioner }\end{array}$} \\
\hline & & Sesuai & Tidak Sesuai \\
\hline \multicolumn{4}{|c|}{ Jerawat } \\
\hline 1. & $\begin{array}{l}\text { Apabila saya } \\
\text { berjerawat, saya tidak } \\
\text { mengatasinya. }\end{array}$ & $\begin{array}{c}95 \\
(79,2 \%)\end{array}$ & $\begin{array}{c}25 \\
(20,8 \%)\end{array}$ \\
\hline 2. & $\begin{array}{l}\text { Saya selalu } \\
\text { membersihkan wajah } \\
\text { dua kali sehari. }\end{array}$ & $\begin{array}{c}100 \\
(83,3 \%)\end{array}$ & $\begin{array}{c}20 \\
(16,7 \%)\end{array}$ \\
\hline 3. & $\begin{array}{l}\text { Apabila saya } \\
\text { berjerawat, saya } \\
\text { berkonsultasi ke } \\
\text { klinik kecantikan }\end{array}$ & $\begin{array}{c}23 \\
(19,2 \%)\end{array}$ & $\begin{array}{c}97 \\
(80,8 \%)\end{array}$ \\
\hline 4. & $\begin{array}{l}\text { Saya selalu menjaga } \\
\text { pola hidup untuk } \\
\text { menghindari } \\
\text { berjerawat }\end{array}$ & $\begin{array}{c}67 \\
(55,8 \%)\end{array}$ & $\begin{array}{c}53 \\
(44,2 \%)\end{array}$ \\
\hline 5. & $\begin{array}{l}\text { Saya menghindari } \\
\text { makan cokelat dan } \\
\text { junk food untuk } \\
\text { mencegah berjerawat }\end{array}$ & $\begin{array}{c}22 \\
(18,3 \%)\end{array}$ & $\begin{array}{c}98 \\
(81,7 \%)\end{array}$ \\
\hline \multicolumn{4}{|c|}{ Produk antiacne } \\
\hline 6. & $\begin{array}{l}\text { Saya membeli produk } \\
\text { physical treatments } \\
\text { (scrub, pore pack, } \\
\text { dan paper oil) untuk } \\
\text { mencegah berjerawat. }\end{array}$ & $\begin{array}{c}75 \\
(62,5 \%)\end{array}$ & $\begin{array}{c}45 \\
(37,5 \%)\end{array}$ \\
\hline 7. & $\begin{array}{l}\text { Saya selalu membeli } \\
\text { salep antiacne jika } \\
\text { berjerawat }\end{array}$ & $\begin{array}{c}38 \\
(31,7 \%)\end{array}$ & $\begin{array}{c}82 \\
(68,3 \%)\end{array}$ \\
\hline 8. & $\begin{array}{l}\text { Saya memilih produk } \\
\text { skincare sesuai } \\
\text { dengan tipe kulit } \\
\text { saya. }\end{array}$ & $\begin{array}{c}97 \\
(80,8 \%)\end{array}$ & $\begin{array}{c}23 \\
(19,2 \%)\end{array}$ \\
\hline 9. & $\begin{array}{l}\text { Ketika membeli } \\
\text { produk antiacne, } \\
\text { saya selalu melihat } \\
\text { komposisi produk }\end{array}$ & $\begin{array}{c}62 \\
(51,7 \%)\end{array}$ & $\begin{array}{c}58 \\
(48,3 \%)\end{array}$ \\
\hline 10. & $\begin{array}{l}\text { Saya selalu membeli } \\
\text { produk jerawat yang } \\
\text { mahal karena saya } \\
\text { percaya produk } \\
\text { tersebut berkualitas. }\end{array}$ & $\begin{array}{c}86 \\
(71,7 \%)\end{array}$ & $\begin{array}{c}34 \\
(28,3 \%)\end{array}$ \\
\hline
\end{tabular}

\section{KESIMPULAN}

Berdasarkan hasil survei mengenai pengetahuan, sikap, dan tindakan mahasiswa terkait cara mengatasi jerawat, diperoleh kesimpulan bahwa sebanyak 73 responden $(60,8 \%)$ belum mengetahui bahwa sediaan salep antiacne yang sudah digunakan dan masih tersisa hanya boleh digunakan paling lama selama 3 bulan. Sebanyak 90 responden $(75,0 \%)$ kurang sadar bahwa perlunya berkonsultasi ke dokter atau klinik kecantikan jika berjerawat dan sebanyak 98 responden $(81,7 \%)$ tidak menghindari junk food atau cokelat dalam mencegah timbulnya jerawat.

\section{DAFTAR PUSTAKA}

Kementerian Kesehatan RI 2012, Buku Media KIE Aku Bangga Aku Tahu. Kementerian Kesehatan RI, Jakarta.

Madelina, W, Sulistiyaningsih 2018, 'Review: resistensi antibiotik pada terapi pengobatan jerawat', Farmaka, 16(2), pp. 105-117.

Marliana, M, Sartini, S, Karim, A 2018, 'Efektivitas beberapa produk pembersih wajah antiacne terhadap bakteri penyebab jerawat propionibacterium acnes', Biolink (Jurnal Biologi Lingkungan, Industri, Kesehatan), 5(1), pp. 31-41.

Movita, T 2013, 'Acne vulgaris', CDK-203, 40, pp. 269-272.

Muliyawan, D, Suriana, N 2013, A-Z Tentang Kosmetik, PT Elex Media Komputindo, Jakarta.

Murtiastutik, D 2009, HIV \& AIDS dengan Kelainan Kulit. Universitas Airlangga, Surabaya.

Notoatmodjo, S 2010, Ilmu Perilaku Kesehatan, Catatan Pertama, PT. Rineka Cipta, Jakarta.

Notoatmodjo, S., 2012, Promosi Kesehatan dan Perilaku Kesehatan, Edisi Revisi, PT. Rineka Cipta, Jakarta.

Okoro, E, Ogunbiyi, A, George, A 2016, 'Prevalence and pattern of acne vulgaris among adolescents in Ibadan, south-west Nigeria', Journal of the Egyptian Women's Dermatologic Society, 13(1), pp. 7-12.

Quairoli, K, Foster, KT 2009, Acne. In: Berardi, Rosemary, R, Ferreri, SP, Handbook of Nonprescription Drugs 16th Edition, American Pharmacist Association, Washington.

Resti, R, Tarigan, HS 2015, 'Treatment for acne vulgaris', Journal of Majority, 4(2), pp. 87-95. 